\title{
PERLINDUNGAN HUKUM TERHADAP PEKERJA DENGAN PERJANJIAN KERJA WAKTU DI INDONESIA
}

\author{
Agus Antara Putra, I Nyoman Putu Budiartha, Desak Gde Dwi Arini \\ Fakultas Hukum Universitas Wrmadewa, Denpasar-Bali, Indonesia \\ antaraputra613@gmail.com, budiarthaputu59@gmail.com, arinidesak1966@gmail.com
}

\begin{abstract}
Abstrak
Pada zaman sekarang ini, sering terjadi kekaburan norma terhadap aktifitas yang dilakukan pekerja melalui sistem perjanjian kerja waktu tertentu. Para pekerja mengalami masalah dalam pelaksanaannya terutama dalam pemenuhan hak pekerja yang tidak dipenuhi pengusaha. Penelitian ini bertujuan untuk menganalisis pengaturan Perjanjian Kerja Waktu Tertentu (PKWT) di Indonesia, dan untuk mengetahui perlindungan hukum terhadap pekerja dengan Perjanjian Kerja Waktu Tertentu (PKWT) di Indonesia. Penelitian ini menggunakan metode penelitian hukum normatif melalui pendekatan perundangan-undangan dan pendekatan konsep. Hasil penelitian menunjukkan bahwa pengaturan hukum perjanjian kerja waktu tertentu di Indonesia telah diatur dari pedoman hukum tertinggi yang berdasar pada Undang-Undang Dasar tahun 1945 sampai dengan berbagai Keputusan Menteri. Kemudian, perlindungan hukum terhadap pekerja dengan perjanjian kerja waktu tertentu dilaksanakan secara preventif dan represif. Adapun pengawasan dilaksanakan untuk menjaga kelangsungan perjanjian kerja sesuai dengan peraturan perundang-undangan.
\end{abstract}

Kata Kunci: Perlindungan Hukum; Pekerja; Perjanjian Kerja Waktu Tertentu

\begin{abstract}
In this day and age, norms often get blurred against the activities carried out by workers through a system of working agreements for a certain time. Workers get problems in the implementation of the regulation especially in fulfilling workers' rights which are not fulfilled by employers. This study aims to analyze the arrangements for a certain time work agreement in Indonesia, and to find out the legal protections for workers with a certain time working agreement in Indonesia. This study uses a normative legal research method through a statutory approach and a conceptual approach. The results show that the legal arrangements for a certain time work agreement in Indonesia have been regulated from the highest legal guidelines based on the 1945 Constitution to various Ministerial Decrees. Then, legal protection for workers with a work agreement for a certain time is carried out in a preventive and repressive manner. Supervision is also carried out to maintain the continuity of work agreements in accordance with statutory regulations.
\end{abstract}

Keywords: Legal Protection; Workers; Fixed Term Work Agreement

\section{PENDAHULUAN}

Negara Kesatuan Republik Indonesia merupakan negara berkembang dan mempunyai potensi besar dalam upaya peningkatan pembangunan nasional. Dalam pembangunan perkembangan suatu bangsa ditentukan oleh usaha dari bangsa itu sendiri untuk mencapai tujuan dan cita-citanya (Wibowo, 2008). Tujuan pembangunan nasional adalah mewujudkan suatu masyarakat yang adil dan makmur, merata baik materiil dan spiritual berdasarkan Pancasila dan Undang-Undang Dasar Negara Republik Indonesia Tahun 1945 di dalam wadah Negara Kesatuan Republik Indonesia yang merdeka, bersatu dan berkedaulatan rakyat. Tujuan pembangunan tercantum secara rinci dalam pembukaan UndangUndang Dasar 1945 alinea ke IV, yaitu melindungi segenap bangsa Indonesia dan seluruh tumpah darah Indonesia, memajukan kesejahteraan umum, mencerdaskan kehidupan bangsa dan ikut melaksanakan ketertiban dunia berdasar kemerdekaan, perdamaian abadi dan keadilan sosial.

Sesuai amanat nasional semua warga negara Indonesia berhak mendapat pekerjaan untuk kehidupan yang layak. Sejalan dengan upaya pembangunan dan tujuan nasional yang terkandung dalam Pembukaan Undang-Undang Dasar Republik 1945. Salah satu bidang untuk mencapai tujuan 
nasional sebagai upaya pembangunan nasional adalah di bidang ketenagakerjaan karena mencakup berbagai segi hukum khususnya ketenagakerjaan, ekonomi, sosial dan kemanusiaan. Berkaitan dengan ketentuan itu, pemerintah mempunyai kewajiban untuk mengupayakan kesejahteraan masyarakat. Arah pembangunan terwujud dalam kebijakan hukum bidang ketenagakerjaan yaitu mengembangkan ketenagakerjaan secara menyeluruh dan terpadu yang diarahkan pada peningkatan kompetensi dan kemandirian tenaga kerja, peningkatan pengupahan, penjaminan kesejahteraan, perlindungan kerja dan kebebasan berserikat serta perlindungan hukum bagi pekerjanya (Charda S., 2014; Zulkarnaen \& Utami, 2016). Pengaruh pemerintah bidang ketenagakerjaan diwujudkan dengan peraturan pemerintah mengenai ketenagakerjaan. Ketenagakerjaan merupakan masalah yang berkaitan antara pekerja, pengusaha, perjanjian, perlindungan hukum dan pengawasan. Hubungan pekerja dengan pengusaha disebut perjanjian kerja. Perjanjian kerja digunakan sebagai sarana pemenuhan hak dan kewajiban pekerja dan pengusaha yang harus dilaksanakan dengan baik karena dalam pelaksanaannya sering terjadi pelanggaran dari pengusaha sebagai pemberi kerja yang notabene bisa mengintervensi bawahannya.

Perjanjian kerja merupakan perjanjian dimana pihak pekerja mengikatkan diri dengan pengusaha untuk bekerja dengan menerima upah (Soepomo, 2003). Hubungan kerja adalah bagian penting dalam ketenagakerjaan yaitu hubungan antara buruh dan majikan setelah adanya perjanjian kerja merupakan hubungan kerja dengan pihak buruh mendapatkan imbalan dan pemberi kerja menyanggupi mempekerjakan pihak (Husni, 2000). Dari penjelasan tersebut adanya keterkaitan antara dua pihak yang saling membutuhkan. Terkait dengan implementasi pekerjaan dengan perusahaan, perlu diketahui permasalahan perlindungan hukum khususnya untuk tenaga kerja. Perlindungan hukum pekerja bermaksud untuk menjaga hak dasar, menjaga perlakuan diskriminasi untuk mewujudkan kesejahteraan pekerja tanpa mengesampingkan kepentingan pengusaha dan dunia usaha. Karena sering terjadi pekerja sudah melaksanakan kewajiban namun hak mereka diabaikan oleh majikannya.

Perlindungan hukum terhadap pekerja berkaitan dengan perjanjian kerja dalam hal ini adalah Perjanjian Kerja Waktu Tertentu (PKWT). Pelaksanaan PKWT menurut jenis dan sifatnya dijabarkan sebagai pekerjaan yang bersifat sementara, musiman, pekerjaan yang berhubungan dengan produk serta tenaga harian lepas tetapi tidak ada peraturan yang mengatur pasti akan pekerjaan apa yang dapat dilaksanakan oleh buruh dengan perjanjian kerja ini (Shalihah, 2017). Kerugian penerapan sistem perjanjian kerja ini adalah selain tidak memberikan kepastian terhadap hubungan kerja yang ada, upah kerja yang diberikan juga lebih murah serta kurangnya bahkan tidak ada perhatian sama sekali dari pengusaha, karena status pekerja hanya sebagai karyawan tidak tetap dan hanya bekerja untuk jangka waktu tertentu. Dewasa ini sistem perjanjian tidak tetap dengan rentang waktu sudah semacam menjadi kebiasaan baru para investor atau pemberi kerja demi memaksimalkan keuntungan. Melihat fenomena tersebut pihak yang dirugikan para buruh yang menajalani sistem perjanjian tidak tetap. Hal ini dikarenakan ketentuan yang seharusnya dan sewajarnya diberikan tidak dilaksanakan. Selain itu terdapat perbedaan pada perlindungan yang diterima oleh para buruh.

Penegakan hukum terhadap keadaan ini menjadi sebuah dilematis, karena di tengah keadaan pengangguran yang sangat tinggi secara logika akan terpikir lebih baik menyediakan lapangan pekerjaan yang banyak dengan gaji yang kecil dan syarat kerja serta ketentuan kerja yang tidak kualifikasi tinggi. Atau dengan membuka sedikit lapangan pekerjaan dengan syarat dan ketentuan kerja atau kualifikasi yang tinggi dengan pengupahan yang layak namun, satu sisi banyak pengangguran yang akan ada. Memang idealnya menyediakan banyak lapangan pekerjaan dengan pengupahan yang layak dan sesuai ketentuan serta perlindungan hukumnya terjamin. Namun dalam pelaksanaan Perjanjian Kerja Waktu Tertentu (PKWT), masih banyak ditemukan penyimpangan, pihak pemberi kerja yang enggan mengangkat menjadi pekerja tetap. Hal ini terjadi akibat ketidakjelasan norma (kekaburan norma) mengenai pekerjaan yang dapat dijabat pekerja dengan perjanjian ini sehingga menjadi ambigu dengan pekerjaan pekerja dengan perjanjian kerja yang bersifat tetap. Kemudian perbandingan antara perjanjian kerja ini dengan pekerja outsourcing atau dengan tenaga kerja asing malah lebih jelas pengaturannya. Serta tidak adanya peraturan perundangan-undangan yang khusus mengatur tentang jenis pekerjaan PKWT, apalagi tidak adanya sanksi tegas jika pengusaha melanggar PKWT dan tidak bersedia mengangkat menjadi pekerja tetap sehingga harus segera ada tindakan penanggulangan mengenai gejala hukum yang terjadi mengingat banyak pekerja yang berkerja dengan sistem perjanjian ini. 
Berdasarkan uraian di atas, maka penelitian ini dirumuskan untuk mengetahui pengaturan Perjanjian Kerja Waktu Tertentu (PKWT) di Indonesia dan untuk mengetahui perlindungan hukum terhadap pekerja dengan Perjanjian Kerja Waktu Tertentu (PKWT) di Indonesia.

\section{METODE PENELITIAN}

Tipe penelitian ini adalah penelitian hukum normatif. Penelitian ini menggunakan pendekatan perundang-undangan (statute approach) dan pendekatan konsep (conceptual approach). Untuk menunjang pembahasan terhadap permasalahan, maka ada beberapa bahan hukum yang dijadikan sebagai sumber data dalam penelitian ini, yakni bahan hukum primer yang bersumber pada peraturan perundang-undangan yang sesuai masalah yang di bahas di dalam penelitian. Kemudian, bahan hukum sekunder yang bersumber pada kepustakaan, jurnal hukum, majalah, dan surat kabar. Teknik penggabungan sumber-sumber bahan hukum melalui pendataan, pembelajaran dan pendalaman bahan hukum primer dan sekunder sesuai dengan penelitian yaitu dengan membuat tulisan dan melakukan pengelompokan terhadap bahan-bahan tersebut. Pengaturan perlu dilakukan secara horizontal seraya meneliti rumusan perundang-undangannya dalam ini adalah peraturan perundang-undangan. Hal ini dilakukan untuk mempermudah melakukan analisis terhadap obyek penelitian.

\section{HASIL PENELITIAN DAN PEMBAHASAN}

\section{Pengaturan Hukum Perjanjian Kerja Waktu Tertentu di Indonesia}

Perikatan mencakup pengertian yang lebih luas dibanding perjanjian karena mengandung pengertian hubungan hukum yang timbul dari peraturan perundang-undangan. Sedangkan perjanjian adalah kata yang mengandung kesanggupan tertulis atau tidak tertulis. Disamping sumber lainnya perjanjian merupakan sumber perikatan. Perjanjian dapat disebut persetujuan karena para pihak setuju melakukan pekerjaan. Dapat disimpulkan bahwa perjanjian atau persetujuan bersumber dari perikatan dimana harus ada minimal dua orang atau dua pihak melaksanakannya. Perjanjian kerja waktu tertentu merupakan perjanjian kerja pihak pekerja dengan pihak pemberi kerja dengan sifat tidak tetap. Beberapa unsur yang wajib dari perjanjian kerja waktu tertentu yaitu, unsur pekerja/buruh, unsur perikatan/perjanjian dan perlindungan hukumnya. Ketiga unsur tersebut saling mengaitkan satu sama lainnya. Pekerja sebagai tombak utama, perjanjian sebagai sarana dalam hubungannya serta perlindungan adalah hak yang harus dibayarkan pemberi kerja.

Pelaksanaan Perjanjian Kerja Waktu Tertentu (PKWT) di Indonesia merupakan bentuk penyegaran pada dunia kerja guna melindungi pekerja untuk memenuhi amanat negara untuk pondasi kedepan. Dengan adanya perjanjian ini juga diharapkan para buruh tidak khawatir mengenai hak mereka. Serta meningkatkan harga diri para pekerja dan mewujudkan masyarakat yang sejahtera dan makmur agar tidak ada lagi diskriminasi yang dialami buruh yang dalam hal ini berstatus sebagai bawahan dari pengusaha. Penyebab terjadinya akibat tersebut adalah perkembangan perekonomian yang demikian cepat. Sehingga perusahaan dituntut untuk memberikan pelayanan yang serba lebih baik. Akan tetapi dengan biaya yang lebih murah sehingga dapat menghasilkan keuntungan yang sebesar-besarnya. Dengan demikian banyak perusahaan yang mengubah struktur manajemen perusahaan mereka agar menjadi lebih efektif dan efisien serta biaya yang dikeluarkan perusahaan dalam melakukan kegiatan produksinya lebih kecil, dimana salah satunya dengan cara memborongkan pekerjaan kepada pihak lain atau dengan cara mempekerjakan para pekerja dengan sistem pekerjaan yang tidak tetap.

Secara tidak langsung perlindungan hukum berkaitan dengan perjanjian kerja waktu tertentu sebagaimana telah dibahas sebelumnya tentang warga negara mendapat kesempatan tanpa diskriminasi oleh siapapun untuk mendapatkan pekerjaan. Karena itu pemberi kerja wajib memberikan hak-hak para pekerja tanpa membedakan semua unsur termasuk unsur politik, agama, warna kulit dan lainnya. Beberapa hak tersebut antara lain adalah hak perlindungan ekonomi, hak perlindungan sosial dan hak perlindungan teknis. Perlindungan ekonomi merupakan dalam bentuk penghasilan yang cukup termasuk saat tidak mampu bekerja di luar kehendak. Perlindungan sosial adalah jaminan kesehatan dan berorganisasi. Sedangkan perlindungan teknis adalah perlindungan keselamatan dan keamanan saat bekerja (Soewono, 2018). Secara teknis dijabarkan tentang perjanjian kerja yang bersifat tidak tetap merupakan hubungan dari dua pihak yaitu buruh dan pemberi kerja untuk melaksanakan pekerjaan dalam rentang waktu tertentu. Dan hanya untuk pekerjaan tertentu yang menurut kegiatan pekerjaanya selesai dengan rentang waktu tertentu. Misalnya pekerjaan yang 
paling lama tiga tahun, pekerjaan selesai sekali, pekerjaan pada musim tertentu serta pekerjaan tambahan yang masih dalam masa percobaan.

Sedangkan perjanjian kerja yang bersifat tetap merupakan perjanjian yang sangat umum dan tidak memiliki jangka waktu berlakunya, tidak akan berakhir akibat pemberi kerja meninggal atau hibah kepada orang lain serta tidak akan berakhir akibat penjualan yang menurun. Dibuat secara tertulis atau lisan dan tidak wajib mendapat pengesahan serta dapat mensyaratkan masa percobaan selama tiga bulan dengan pembayaran upah pekerja sesuai upah minimum. Jenis perjanjian pengaturannya lebih jelas dibandingkan perjanjian kerja waktu tertentu. Namun untuk menekan biaya perusahaan beralih menggunakan PKWT yang secara ekonomi lebih hemat. Dengan menerapkan sistem perjanjian kerja ini perusahaan dapat menekan biaya menjadi lebih hemat, karena tidak memerlukan pekerja dengan jumlah yang banyak. Sebagaimana diketahui apabila perusahaan memiliki pekerja dengan jumlah banyak, maka perusahaan harus memberikan berbagai tunjangan untuk kesejahteraan para pekerja, seperti tunjangan pemeliharaan kesehatan, tunjangan pemutusan hubungan kerja tunjangan penghargaan kerja dan sebagainya. Tetapi jika mempekerjakan para pekerja dengan sistem perjanjian ini bisa menekan biaya tersebut.

Implementasi di lapangan yaitu di SMA Negeri 1 Blahbatuh yang terletak di Jalan Astina Raya Blahbatuh, tanggal 22 Juni 2020 selain penerapan sistem perjanjian kerja waktu tertentu yang tidak sesuai dengan ketentuan atau peraturan yang berlaku. Seperti yang terjadi pada SMA Negeri 1 Blahbatuh, dalam hal ini pihak sekolah mempekerjakan cleaning service dengan perjanjian kerja waktu tertentu selama lebih dari tiga tahun, yang sebenarnya jenis pekerjaan tersebut lebih condong dengan sistem pekerjaan outsourcing yang menggunakan pihak ketiga serta besaran upah yang diterima tidak sesuai dengan upah minimum kabupaten atau provinsi. Berdasarkan pemaparan diatas, dapat dirangkum bahwa peraturan perundangan-undangan tentang ketenagakerjaan di Indonesia sudah memberikan persyaratan, bilamana jika persyaratan-persyaratan tersebut dilanggar atau ada penyimpangan oleh pengusaha sebagai pihak yang lebih kuat kedudukannya secara ekonomi dalam pembuatan perjanjian kerja waktu tertentu akan berakibat hukum jika dibuat secara lisan, untuk pekerjaan tetap, diperpanjang lebih dari satu kali, saat memperpanjang perjanjian tidak memberitahu 7 hari sebelumnya secara tertulis, dan bekerja selama tiga bulan beruntun atau dua puluh satu hari lebih tidak diberi hak cuti.

\section{Perlindungan Hukum Terhadap Pekerja dengan Perjanjian Kerja Waktu Tertentu (PKWT) di Indonesia}

Perlindungan hukum merupakan suatu kebutuhan yang sangat mendasar dalam ketenagakerjaan, khususnya dalam bentuk perjanjian kerja dengan pengusaha atau pemberi kerja. perlindungan buruh bermaksud menjaga hak dasar dan kesempatan serta menghindari diskriminasi dengan tujuan mensejahterakan para buruh tetapi tetap memperhatikan kemajuan dunia usaha. Ditengah maraknya bahaya penyelewengan atau ketimpangan yang ditimbulkan perjanjian yang merugikan pekerja/buruh. Dengan perlindungan hukum diharapkan pekerja dapat bekerja dengan nyaman, sehingga meningkatkan produksi dan kehidupan yang lebih baik serta tidak ada diskriminasi yang dialami oleh para pekerja. Perlindungan hukum adalah perlindungan akan harkat dan martabat, serta pengakuan terhadap hak asasi manusia yang dimiliki oleh subyek hukum dalam negara hukum dengan berdasarkan pada ketentuan hukum yang berlaku di negara tersebut guna mencegah terjadinya kesewenang-wenangan. Perlindungan hukum itu pada umumnya berbentuk suatu peraturan tertulis, sehingga sifatnya lebih mengikat dan akan mengakibatkan adanya sanksi yang harus dijatuhkan kepada pihak yang melanggarnya (Hadjon, 1987)

Dalam pelaksanaan hak dan kewajiban, perlu diketahui permasalahan perlindungan hukum khususnya untuk tenaga kerja/buruh. Perlindungan hukum buruh bertujuan untuk menghapus diskriminasi dan menjaga agar para buruh lebih dimanusiakan, sehingga dapat meningkatkan kesejahteraan hidup para buruh. Untuk menjalankan proses dari perlindungan terhadap pekerja memerlukan perencanaan dan pelaksanaan secara komprehensif, terpadu dan berkesinambungan. Pada umumnya tidak boleh ada pemberlakuan tidak adil (diskriminasi) antara sesama pekerja atau antara pekerja/buruh dengan perusahaan. Berkaitan dengan pengaturan perjanjian dengan rentang waktu tertentu yang mempunyai permasalahan implementasi jenis pekerjaan yang dapat dilaksanakan pekerja serta tidak adanya undang-undang yang secara tegas mengatur akan sanksi atas pelanggaran yang dilakukan oleh pengusaha/pemberi kerja, dapat diatasi dengan melaksanakan perlindungan 
hukum secara preventif dan represif serta melaksanakan pengawasan akan kedua jenis perlindungan hukum tersebut. Seperti yang ditegaskan oleh Hadjon, (1987) yang menyatakan perlindungan hukum dapat dilaksanakan secara preventif dan represif. Dengan mengikuti konsep itu, paling tidak ada dua pihak yang terlibat, dimana difokuskan kepada satu pihak dengan tindakannya, berhadapan dengan rakyat yang dikenai tindakan pemerintah. Karena itu, peraturan perundang- undangan memfasilitasi pengajuan keberatan dari rakyat sebelum keputusan final merupakan bentuk perlindungan hukum preventif. Perlindungan hukum represif dilaksanakan untuk rakyat saat di pengadilan.

Perlindungan hukum preventif bertujuan untuk melindungi pekerja/buruh melalui peraturan perundang-undangan, yang mencakup dari berbagai segi ketenagakerjaan seperti perlindungan mengenai kesejahteraan, perlindungan kesehatan, perlindungan keselamatan kerja serta perlindungan hukum dalam berserikat. Ditengah maraknya bahaya, penyelewengan, atau ketimpangan yang ditimbulkan oleh perjanjian tersebut sangat merugikan pekerja/buruh. Dengan adanya perlindungan hukum diharapkan pekerja/buruh dapat bekerja dengan tenang sehingga dapat meningkatkan produksi dan kesejahteraan untuk kualitas hidup yang lebih baik mengingat banyak pekerja yang bekerja dengan perjanjian kerja ini. Sedangkan perlindungan hukum yang bersifat represif menyangkut hak pekerja dalam peraturan perundang-undangan untuk menjaga hak normatifnya jika ada perselisihan atau penyelewengan lainnya yang dilakukan pengusaha/pemberi kerja. Lebih lanjut perlindungan secara represif merupakan perlindungan yang dilaksanakan saat pekerja mengalami permasalahan baik intern pekerja maupun dengan pengusaha.

Berdasarkan pemahaman yang telah diuraikan diatas, perlindungan hukum berfungsi meberikan rasa keadilan, kepastian hukum dan kemanfaatan bagi dunia usaha. Perlindungan pekerja merupakan hal yang diberikan sesuai dengan peraturan perundang-undangan. Perlindungan preventif yang lebih sederhana berarti pencegahan maupun yang bersifat represif yaitu saat terjadinya permasalahan, berupa tertulis maupun tidak tertulis. Perselisihan hubungan industrial merupakan hal yang kerap terjadi dalam dunia ketenagakerjaan. Perbedaan pendapat merupakan awal terjadinya perselisihan berakibat pertentangan perngusaha dengan kelompok pekerja. Ada empat jenis perselisihan dalam dunia industri yang dibedakan menjadi perselisihan kelompok pekerja, perselisihan akan hak, perselisihan tentang kepentingan dan perselisihan akibat pemutusan hubungan kerja dari perusahaan. Upaya menangani perselisihan hubungan industrial dapat dilaksanakan dengan cara pengadilan dan non litigasi (Penggabean, 2007). Penyelesaian secara non litigasi merupakan penyelesaian yang berkualitas di luar pengadilan dengan tetap memakai dasar hukum. Beberapa penyelesaian perselisihan industrial dengan memakai cara demikian antara lain penyelesaian bipartite, penyelesaian melalui mediasi, penyelesaian melalui konsiliasi dan penyelesaian melalui arbitrase. Dalam dunia industri untuk menjaga peraturan perundang- undangan berlaku sesuai kaidah diberlakukan pengawasan pada bidang ini. Pengawasan berfungsi menegakkan hukum yang berlaku sebagai sebuah sistem untuk menjaga keseimbangan dalam dunia kerja. Hal ini dapat menjaga kenyamanan serta suasana kondusif saat bekerja.

Pengawasan perburuhan untuk seluruh Indonesia telah diatur dalam peraturan perundangundangan tentang hak seorang pengawas terhadap perusahaan saat melaksanakan pengawasan. Maksud pengawasan perburuhan dapat dijabarkan seperti memastikan peraturan perundang-undangan berlaku sebagaimana mestinya, mencari bahan mengenai hubungan kerja untuk membuat peraturan dan menlaksanakannya apa yang sudah diamanatkan. Fungsi pengawasan ketenagakerjaan adalah untuk menjamin masalah yang terkait dengan ketenagakerjaan sesuai dengan peraturan yang berlaku termasuk mengenai perlindungan buruh, mengumpulkan informasi yang efektif untuk mentaati peraturan perundang-undangan terutama para untuk para pengusaha dan menyampaikan permasalahan yang terjadi kepada pemerintah yang selanjutnya bisa ditindaklanjuti. Dari penjabaran diatas, perlindungan hukum preventif dan represif serta pengawasan terhadap perlindungan pekerja dengan perjanjian kerja ini di Indonesia bertujuan untuk melindungi pekerja/buruh dengan sistem perjanjian ini. Perlindungan yang dilakukan melalui peraturan perundang-undangan (preventif), kemudian perlindungan dari segi pengendalian (represif) jika terjadi perselisihan dan pengawasan yang dilakukan instansi terkait di bidang ketenagakerjaan. 


\section{SIMPULAN DAN SARAN}

\section{Simpulan}

Berdasarkan uraian di atas, dapat disimpulkan bahwa pengaturan Hukum Perjanjian Kerja Waktu Tertentu (PKWT) di Indonesia, sudah diatur pada pedoman tertinggi sampai dengan Keputusan Menteri di Indonesia, serta ditunjang juga dari ketentuan dalam Pasal-Pasal yang diatur dalam Kitab Undang-Undang Hukum Perdata di Indonesia. Kemudian, perlindungan hukum terhadap pekerja dengan perjanjian kerja waktu tertentu di Indonesia secara preventif sudah dijamin dalam peraturan perundang-undangan. Sedangkan perlindungan hukum yang bersifat represif dapat dilakukan pekerja dengan mengajukan gugatan perselisihan hubungan industrial melalui mekanisme Penyelesaian Perselisihan Hubungan Industrial (PPHI) di Indonesia.

\section{Saran}

Beberapa saran yang hendak disampaikan, yakni pemerintah diharapkan melakukan pengkajian ulang terhadap peraturan perundang-undangan yang mengatur perjanjian kerja waktu tertentu terutama yang menimbulkan perbedaan penafsiran atau ketidakjelasan norma terhadap jenis dan sifat pekerjaan PKWT baik dari pihak pengusaha, pekerja, mediator dan hakim. Kemudian, para pengusaha atau pemberi kerja agar melaksanakan isi-isi dalam perjanjian sesuai ketentuan perundangan yang berlaku. Agar perlindungan hukum dan kesejahteraan pekerja atau buruh dengan perjanjian kerja ini terjamin sehingga pekerja dapat berkehidupan secara layak.

\section{DAFTAR PUSTAKA}

Charda S., U. (2014). Reformasi Politik Hukum Ketenagakerjaan dalam Kebijakan Pemerintah Indonesia. Jurnal Wawasan Hukum, 31(2), 121-153.

Hadjon, P. M. (1987). Perlindungan Hukum bagi Rakyat Indonesia. Bina Ilmu.

Husni, L. (2000). Pengantar Hukum Ketenagakerjaan Indonesia. PT. Raja Grafindo Persada.

Penggabean, H. P. (2007). Hukum Acara Penyelesaian Perselisihan Hubungan Industrial. Jala Permata.

Shalihah, F. (2017). Perjanjian Kerja Waktu Tertentu (PKWT) dalam Hubungan Kerja Menurut Hukum Ketenagakerjaan Indonesia dalam Perspektif HAM. In Uir Law Review (Vol. 1, Issue 02, pp. 149-160).

Soepomo, I. (2003). Pengantar Hukum Perburuhan. Djambatan.

Soewono, D. H. (2018). Perjanjian Kerja Waktu Tertentu: Tinjauan dari Perspektif Yuridis Sosiologis Reflektif Kritis. Jurnal Elektronik Universitas Kediri.

Wibowo, E. (2008). Perencanaan dan Strategi Pembangunan di Indonesia. Jurnal Ekonomi Dan Kewirausahaan, 8(1), 16-24.

Zulkarnaen, A. H., \& Utami, T. K. (2016). Perlindungan Hukum terhadap Pekerja dalam Pelaksanaan Hubungan Industrial. PADJADJARAN Jurnal Ilmu Hukum, 3(2), 407-427. 